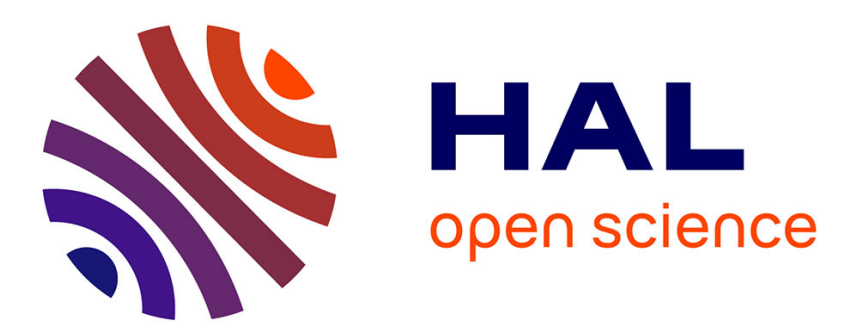

\title{
Keynesian and Austrian Perspectives on Crisis, Shock Adjustment, Exchange Rate Regime and (Long-Term) Growth
}

\author{
Mathilde Maurel, Gunther Schnabl
}

\section{- To cite this version:}

Mathilde Maurel, Gunther Schnabl. Keynesian and Austrian Perspectives on Crisis, Shock Adjustment, Exchange Rate Regime and (Long-Term) Growth. 2011. halshs-00565231

\section{HAL Id: halshs-00565231 \\ https://shs.hal.science/halshs-00565231}

Submitted on 11 Feb 2011

HAL is a multi-disciplinary open access archive for the deposit and dissemination of scientific research documents, whether they are published or not. The documents may come from teaching and research institutions in France or abroad, or from public or private research centers.
L'archive ouverte pluridisciplinaire HAL, est destinée au dépôt et à la diffusion de documents scientifiques de niveau recherche, publiés ou non, émanant des établissements d'enseignement et de recherche français ou étrangers, des laboratoires publics ou privés. 


\section{Documents de Travail du Centre d'Economie de la Sorbonne}

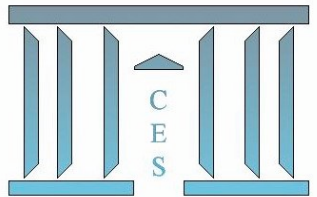

Keynesian and Austrian Perspectives on Crisis, Shock Adjustment, Exchange Rate Regime and (Long-Term) Growth

Mathilde MAUREL, Gunther SCHNABL

2011.04

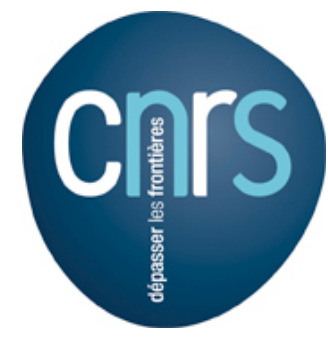




\title{
Keynesian and Austrian Perspectives on Crisis, Shock Adjustment, Exchange Rate Regime and (Long-Term) Growth
}

\section{January 2011}

\author{
Mathilde Maurel \\ CES, Université Paris 1 \\ Panthéon-Sorbonne \\ 106-112 Boulevard de l'Hopital \\ 75647 Paris cedex 13 \\ France \\ mathilde.maurel@univ-paris1.fr
}

\author{
Gunther Schnabl \\ University of Leipzig \\ Grimmaische Straße 12 \\ 04109 Leipzig \\ Germany \\ schnabl@wifa.uni-leipzig.de
}

\begin{abstract}
The 2010 European debt crisis has revived the discussion concerning the optimum adjustment strategy in the face of asymmetric shocks. Whereas Mundell's (1961) seminal theory on optimum currency areas suggests depreciation in the face of crisis, the most recent emergence of competitive depreciations, competitive interest rate cuts or currency wars questions the exchange rate as an adjustment tool to asymmetric economic development. This paper approaches the question from a theoretical perspective by confronting exchange rate based adjustment with crisis adjustment via price and wage cuts. Econometric estimations yield a negative impact of exchange rate flexibility/volatility on growth, which is found to be particularly strong for countries with asymmetric business cycles and during recessions. Based on these findings we support a further enlargement of the European Monetary Union and recommend more exchange rate stability for the rest of the world.
\end{abstract}

JEL codes: F31, F32

Keywords: Exchange rate regime, crisis, shock adjustment, theory of optimum currency areas, Mundell, Schumpeter, Hayek, competitive depreciations, currency war. 


\section{Introduction}

The recent wave of financial and economic crisis - which for the time being culminated in the European debt crisis and "a global currency war" - have revived the discussion about of the adequate adjustment strategy (Sinn 2010, Schnabl and Zemanek 2011). Given the Greek and Irish struggle to regain competitiveness via (nominal) wage cuts, there is a strong argument to maintain the exchange rate as adjustment tool to idiosyncratic shocks. For instance, after the Asian crisis, the crisis countries could engineer a timely recovery based on strong depreciations of their currencies. Similarly, in the year 2002 Argentina stabilised its ailing economy by abandoning a highly criticized currency board. During the most recent wave of crisis, the Central and Eastern European countries adopted different adjustment strategies. Whereas Romania and the Czech Republic responded with interest rate cuts and currency depreciation, the Baltic countries tolerated credit tightening and took decisive measures to curtail wages to restore international competiveness.

The different adjustment strategies in the face of crisis based on inflation or deflation are based on different theoretical frameworks, which were widely discussed during the world economic crisis, either Hawtrey (1919) and Keynes (1936) or Schumpeter (1911) and Hayek (1931). Hawtrey (1919), who dedicated his academic work the deflationary consequences of the return to the gold standard, recommended monetary expansion to prevent dire deflation. After monetary policy had proved unable to revive world economic activity, Keynes (1936) proposed fiscal stimulus as a substitute for the lack of private demand. In the spirit of Hawtrey (1919) and with reference to the 1929 world economic crisis, currently monetary policy is widely regarded as a tool to forestall deflation (Greenspan 2007, Bernanke 2010). Mundell (1961) extended Hawtrey (1919) to a two-country setting and linked it to the question about the appropriate exchange rate regime. He made the seminal argument that the success of exchange rate stabilization strongly hinges on the degree of business cycle synchronization.

In contrast to Hawtrey (1919), Hayek (1931) saw the monetary expansion during crisis as the reason for a more pronounced downturn at some later point of time. In contrast to Keynes (1936), in Schumpeter's (1911) theory the recession is an integral part of economic development with its "cleansing effect" being a necessary prerequisite for a sustained economic recovery. Mundell (1961) implicitly incorporated Schumpeter (1911) by arguing that missing business cycle synchronization could be compensated by sufficient labour market flexibility. Because higher growth can be seen either as the outcome of successful business cycle smoothing (Keynes 1936) 
or a cleansing effect à la Schumpeter (1911) the question about the long-term growth effects of crisis therapies remains an empirical issue. This issue has recently been put forward by Parente and Prescott (2005), who consider growth a non linear process where recoveries after crisis and regime switches are crucial for the overall growth performance and depend upon national institutions and policies.

Yet previous empirical evidence on the impact of exchange rate regime on growth remains mixed as well. From a historical perspective, Eichengreen (2002) argues that the United Kingdom could manage a faster recovery after the world economic crisis, because the gold standard was abandoned earlier. Cerra, Panizza and Saxena (2009) find for a global sample of recent crisis events that monetary expansion and depreciation spur the rebound after crisis. In contrast, Schnabl (2009) finds a positive impact of exchange rate stability on growth in Emerging Europe and East Asia. Aghion et al. (2009) argue that the negative effect of exchange rate volatility on productivity growth vanishes above a critical threshold of financial development. In the same vein, and following Cerra and Saxena (2008), Coricelli and Maurel (2010) highlight that the recovery process to pre-crisis levels depends upon financial institutions and financial reforms.

We aim to augment the existing literature in three ways. First, we discuss shock adjustment during crisis with respect to the implications for the exchange rate regime from both a short-term and long-term perspective based on Hawtrey (1919), Keynes (1936), Schumpeter (1911), Hayek (1931), and Mundell (1961). Second, we perform an econometric investigation for four emerging market country groups and the EU15 with respect to the role of exchange rate stability and price flexibility for growth in the context of business cycle correlation. Third, we aim to isolate the role of the exchange rate regime for growth in recessions.

\section{Exchange Rate Flexibility and Shock Adjustment à la Keynes}

"It is patently obvious that periodic balance of payments crisis will remain an integral feature of the international economic system as long as fixed exchange rates and rigid wage and price levels prevent the terms of trade from fulfilling a natural role in the adjustment process." (Mundell: 1961: 657) 
Given the growing number and dimension of country-specific and regional shocks, which the world has experienced during the last decades, monetary policy independence as advocated by Mundell (1961) seems more than ever necessary to re-equilibrate sudden changes in international competitiveness (Fischer 2001). At the same time, monetary integration has proved to be a shelter against global financial turmoil and imported inflation. The most recent series of crises following the US subprime crisis has highlighted both aspects for the European Monetary Union. In the face of the 2008/09 subprime shock, the common currency insulated the euro area against financial panic and dollar depreciation. During the 2010 Greek and Irish tragedy, the inability to realign competitiveness within a heterogeneous currency union threatened to topple the most ambitious realm of the European integration process.

The fundamental assumption of Mundell's (1961) seminal theoretical framework is - in the tradition of Hawtrey (1919) and Keynes (1936) - that monetary policy fulfils the task of business cycle stabilization. The argument that the "fault lies not with the type of currency area, but with the domain of the currency area" (Mundell 1961: 659) laid the fundament for the notion that optimum currency areas are characterized by synchronized business cycles. As long as countries were subject to the same country specific shock, interest rate changes by a common central bank were regarded as optimal policy solution. For instance the European Central Bank could stabilize the economic activity in the whole euro area during the subprime crisis, because the shock was symmetric. With the central bank fulfilling the task of macroeconomic stabilization, the EMU members could fully reap the microeconomic benefits of fixed exchange rates in form of low transaction costs for international trade and capital flows.

Pressure arises in the case of asymmetric shocks as during the Greek and Irish crisis. Given a one-size-monetary policy (and symmetric country size), the burden of adjustment has to be shared by some more unemployment in the recession region and some inflation in the booming region (Mundell 1961: 660). Given this suboptimal policy outcome, monetary independence of the crisis country seems the optimum device to cope with rising unemployment. From a pure goods market view monetary expansion and the depreciation of the national currency adjust the terms of trade to "jumpstart" the crisis economy via the trade channel. For emerging markets the exchange rate is a particularly effective macroeconomic stabilization tool, as exports constitute a large share of national income and growth dynamics. For the enterprise sector adjustment is facilitated as domestic prices and nominal wages remain in the short-term constant, while prices in foreign currency decline. 
The downside of Mundell's (1961) approach to crisis therapy lies in the long-term consequences and in financial market repercussions. Monetary expansion and currency depreciation will be gradually followed by rising domestic and import prices, which - step by step - erode the previous gains from monetary expansion. This can make a new monetary stimulus to be regarded as necessary. Depreciation in the face of crisis and recession can therefore end into a vicious circle of rising import prices, inflationary pressure and rising nominal and real interest rates, which puts a downward bias on the long-term growth performance (De Grauwe and Schnabl 2008).

Furthermore, Mundell's (1961) thinking on policy response to macroeconomic instability is a pure goods market approach, which fitted well into the world of small capital markets and tight international capital controls of the 1950s and 1960s. In contrast today, international capital markets have grown substantially. The liberalization of international capital flows has facilitated inter-temporal optimization across borders (Schnabl and Zemanek 2011). Substantial stocks of international assets and liabilities have emerged. In this environment exchange rate stabilization has become a matter of financial stability in emerging markets economies, because capital markets are underdeveloped (Eichengreen and Hausmann 1999).

With international credit being mostly provided in foreign currency, emerging markets are vulnerable to exchange rate fluctuations. Countries with a large stock of foreign currency denominated debt (such as most Central and Eastern European countries) are vulnerable to depreciations of the domestic currency (McKinnon and Schnabl 2004a). Countries with a large stock of foreign assets (such as China) exhibit a fear of floating on the appreciation side, as appreciations devalue foreign assets in terms of domestic currency (McKinnon and Schnabl 2004b). Given this currency mismatch in international lending sharp exchange rate fluctuations destabilize financial systems and trigger recessions. In the European Monetary Union rising intra-region liabilities have destabilized the currency union due to their impact on the sustainability of national government debt.

\section{Exchange Rate Stability and Shock Adjustment à la Schumpeter}

The upshot is, that in a world of integrated capital markets keeping the exchange rate pegged during crisis seems the favourable policy choice. As shown by Coricelli and Maurel (2010), 
while the globalisation of financial markets jeopardizes the capacity of emerging countries to rebound after a crisis, countries characterized by better financial institutions recover faster. Mundell's (1961) early work on optimum currency areas acknowledged that even a heterogeneous currency area would work if factor mobility is high enough to equilibrate asymmetric economic developments. For Europe, which embarked on the monetary integration process, Mundell (1961: 661) recommended more labour market mobility.

Acknowledging Ricardos assumption that labour market mobility within countries is high, but low across borders, wage flexibility is the main adjustment tool for asymmetric shocks when exchange rates are stable. To equilibrate international competitiveness, wages and prices in the crisis country have to fall relative to the boom country to re-animate growth under the condition of exchange rate stability. This is currently observed inter alia in the Baltics, Greece and Ireland, which were forced to drastic adjustments in the context of the crisis. But in normal times wage flexibility and labour mobility are considered to be low in Europe (Decressin and Fatas (1995), Bentivogli and Pagano (1999), Fidrmuc (2004)) as compared to the US counterpart (Blanchard and Katz 1992).

Wage cuts during recession have two dimensions. First, during crisis reducing current account deficits requires lowering labour costs by cutting wages (or laying off workers). The austerity imposed on the private sector reduces its real income what aggravates the crisis. Lower consumption leads to lower imports. With wage costs declining, the competitiveness of the export sector is improved and exports grow. The impact of wage cuts on the business cycle follows a "J-curve", it is negative in the short run (because of shrinking investment and consumption) and positive in the longer run (because net exports increase). The economy is rebalanced on the back of rising net exports. Internal adjustment is costly in the short run, but brings benefits in the long run. The implied trade-off is for instance behind the choice made by many Central and Eastern European countries to adhere to the Stability Growth Pact even if they were not formally obliged to enforce it, while coping with asymmetric shocks through internal adjustments (Babetski et al. 2004).

Furthermore, Mundell (1961) did not incorporate the impact of interest rate cuts and depreciation on the marginal efficiency of investment, which he implicitly assumed constant. The boom-andbust cycles, which have been observed since the 1980s in emerging markets and industrial countries show patterns of mal- or overinvestment, i.e. waves of (speculative) investments with 
low marginal efficiency (Hoffmann and Schnabl 2008, Schnabl and Hoffmann 2009), which are threatened to be dismantled during crisis. In contrast to Mundell (1961) who assumes that the crisis originates in a random shock, the real and monetary overinvestment theories by Schumpeter (1911) and Hayek (1931) interpret crisis as the outcome of unsustainable investment activities and speculation during the boom.

Hayek (1931) argues that distorted price signals on financial markets trigger investment above the equilibrium level (which is regarded to be determined by aggregate saving). During the economic upswing the marginal efficiency of realized investment projects declines, as capital market interest rates remain below the long-term equilibrium level (which he calls natural interest rate, at which investment is equal to saving). When rising inflation urges the central bank to lift interest rates, past and future investment becomes subject to a new benchmark. Unprofitable investment (with a marginal efficiency below the increased interest rates) has to be dismantled. Wages and prices fall, and the average marginal efficiency of investment rises.

In Schumpeter's (1911: 350) real overinvestment theory the recession is a process of uncertainty and disorder, which is understood as the search for a new equilibrium. Enterprises threatened by declining demand and prices either exit from the market, consolidate their business activities or struggle to survive on a lower level of production, for instance by changing products or the overall type of business activity. The recession is necessary to force a re-allocation of resources on the enterprise sector. The reorganisation of the production process leads - accompanied by painful individual losses and calamities - to the emergence of new products, the reduction of production costs and - due to declining prices - increasing real incomes. Price reductions and productivity increases during the downswing are seen as the prerequisite for a sustainable recovery.

Schumpeter (1911: 360-369) regards the "cleansing effect" of recessions - despite the negative consequences in form of (temporarily) rising unemployment - as an essential part of a market economy for four reasons. First, speculative investment is to be abandoned. Second, inefficient enterprises have to leave the market. Third, the efficiency of the remaining enterprises is strengthened, as wages decline and productivity rises. Fourth, new enterprises, products and productions processes emerge at the cost of old ones. This implies that general interest rate cuts in response to crisis create invisible costs in form of "the persistence of the unadpated and unlivable" (Schumpeter 1911: 367). The exchange rate regime matters for the cleansing effect, 
because maintaining the peg during the crisis is equivalent to imposing a restructuring process on the enterprise sector. In contrast, discretionary monetary expansion and depreciation would enable the enterprises to circumvent dire restructuring. Investment with low marginal efficiency is conserved and long-term growth perspectives decline.

Whereas Schumpeter's (1911) argument was focused on the private sector it can be extended to the public sector, as in the first generation of currency crisis models (Flood and Garber 1984): After unsustainable public debt has been financed via capital inflows and monetary expansion, the reversal of international capital flows forces a painful restructuring of public expenditure, as mostly recently in Greece: Exuberance in public expenditure, which was before the crisis nurtured by capital inflows, led to rising public, private wages and rising prices. The outcome was the real appreciation of the Greek "currency" as well as to an unsustainable current account deficit. ${ }^{1}$ The reversal of capital flows forced upon Greece a dire restructuring process in both the public and private sector, which is supervised by the IMF and European institutions. ${ }^{2}$

If, nurtured by abundant global liquidity, overinvestment is the momentum behind boom-andcrisis cycles in single countries and different regions, the policy recommendations diverge depending on the theoretical framework. In the view of Hawtrey (1919), Mundell (1961) and Bernanke (2010) monetary expansion and depreciation are sufficient to restore the pre-crisis growth performance. Keynes (1936) recommended fiscal expansion, after monetary expansion seemed to have proved ineffective. In the view of Hayek (1929) interest rate cuts and depreciation conserve low yield investment projects and postpone the crisis to a later point of time. In the view of Schumpeter (1911) monetary expansion and depreciation prevents the reallocation of resources, thereby constituting a drag on long-term growth.

Thus, Hawtrey (1919), Keynes (1936) and Mundell (1961) provide policy recommendations to stabilize the economy in the short term (whereas the long-term consequences are outside the framework). Hayek (1937) and Schumpeter (1911) offer a long-term growth perspective, (but provide no "quick fix" for the economic calamities of crisis). The exchange rate regime can be

\footnotetext{
The integration of the Greek capital markets into the euro area did - in the contrast to Mundell (1961, 1973) - not help to absorb the 2010 asymmetric shock. Instead, the lower transaction costs for intra-European capital flows after the euro introduction contributed to the real divergence among the members of the common currency before the crisis and further aggravated the shock during the crisis.

2 Schumpeter (1929: 356-358) stresses the role of the government in preventing recessions in fulfilling their tasks of cleansing the economy from uncompetitive enterprises. Tolerating trusts, providing public subsidies because of extraordinary circumstances or tariff protection are identified as tools to circumvent the bankruptcy of enterprises.
} 
seen as catalyst for one or the other policy option during asymmetric negative shocks. Under flexible exchange rates, depreciation is the most likely policy outcome in times of crisis. Under fixed exchange rates or in a currency union exchange rate rigidity serves as a catalyst for longterm adjustment via productivity increases, wage austerity, and price cuts. ${ }^{3}$

\section{Empirical Analysis}

Given the different time dimensions of economic theories and stabilization tools, the issue of crisis adjustment via exchange rate flexibility and/or wage/price flexibility is an empirical one. We aim to address the question about the optimum exchange rate regime by isolating the interaction of exchange rate flexibility and price flexibility with respect to their impact on growth dependent on business cycle synchronization. Whereas Mundell (1961) argued that exchange rate adjustment (i.e. price stability) during crisis increases the (short-term) growth performance, in the view of Schumpeter (1911) exchange rate stability during crisis enhances the need for price and wage flexibility, what can be seen as a prerequisite for dynamic long-term growth. The foregoing empirical analysis augments the previous empirical literature as listed in section 1 by analyzing the impact of exchange rate flexibility on growth contingent on business cycle synchronization.

\subsection{Sample, Volatility Measures and Business Cycle Correlation}

To trace the impact of exchange rate flexibility/stability on growth, we choose five country groups for which the choice of the appropriate exchange rate regime has been high on the political agenda: In the EU15 as well as in Central, Eastern and Southeastern Europe (Emerging Europe), the discussion about membership in the European Monetary Union and/or the optimum degree of exchange rate stability against the euro continues to be high on the political agenda. The discussion about the pro and cons of EMU membership and exchange rate stability against the euro was revived during the most recent crisis.

In East Asia and South America the optimum degree of exchange rate stability against the dollar continues to be discussed, in particular since the Asian crisis and drastic US interest rate cuts following the subprime crisis. Most recently, Japan, China and Brazil have been involved in a

3 Duchêne et al. (2004) and Fidrmuc and Maurel (2004) interpret the economic success of EU countries of fixed exchange rates during the nineties in the same vein. Purfield and Rosenberg (2010) provide empirical evidence for the restructuring process of the Baltic countries during the recent crisis. 
discussion on "currency wars" and competitive interest rate cuts (McKinnon 2010). In the Commonwealth of Independent States, Russia's move towards a currency basket and the depreciation of the CIS currencies during the recent crisis has revived the question about the optimum exchange rate policy. In this context, the choice of the anchor currency and therefore the degree of business cycle synchronization with the anchor country plays an important role.

[Insert Figure 1 here]

The five country groups include all countries of the respective region excluding microstates which may bias the sample towards a very high positive effect of exchange rate stability on growth (Rose 2004) - and countries with insufficient data such as Turkmenistan, Uzbekistan, Guyana etc. This brings us to a sample size of 45 countries. (See Table 1 for an overview.) Table 1 also lists the prevailing anchor currencies and thereby the reference countries for measuring business cycle correlation. For the countries in East Asia, South America and the CIS the dollar has been the prevailing target of exchange rate stabilization. Business cycle correlation is measured versus the US.

For the European countries before the introduction of the euro in 1999, the German mark has been the dominant anchor currency. Since then, the euro has become the natural anchor for the European non-EMU countries. Exchange rate stability is measured against the German mark before 1999 and against the euro after 1999. Once a one country has entered the EMU the proxy for exchange rate volatility is set to zero. Business cycle correlation in Europe is measured versus Germany, which is the largest European economy (and therefore a country with a high degree of business cycle correlation with the euro area). For Germany, France as the second largest European economy is used as a reference country to measure business cycle correlation.

[Insert Table 1 here]

The data sources are the IMF International Financial Statistics, IMF World Economic Outlook, and the national central banks. For all macroeconomic data we use yearly frequencies. Yearly volatility measures for exchange rates and price flexibility are computed based on monthly data. The sample period starts in 1994, to avoid putting in the analysis the first years of the nineties, which for most of the European and CIS countries reflect specifics linked to the transition process. 
We use de facto exchange rate volatility measures, because de jure volatility measures are likely to be flawed by fear of floating (Calvo and Reinhart (2002), McKinnon and Schnabl (2004a), De Grauwe and Schnabl (2008)). De facto exchange rate volatility is measured by the standard deviation of monthly percent exchange rate changes $(\sigma)$ and the arithmetic average of percent exchange rate change $(\mu)$. Both measures are summarized by the z-score $\left(z=\sqrt{\mu^{2}+\sigma^{2}}\right)$ as in Schnabl (2009). All three variables are calculated against the euro or the dollar, depending of the anchor currency as listed in Table 1. In the same way, price flexibility is proxied by the standard deviation of monthly changes of the producer price index of the respective year, by the average of monthly changes of producer price index of the respective year, and a combination of both (zscore).

Figure 1 shows the real growth rates of the 45 countries in the sample by country group. We observe different degrees of business cycle synchronization for different countries and different country groups. As we aim to analyze the impact of exchange rate stability on growth in the context of business cycles synchronization we construct two dummies for business cycle synchronization. First to construct a dummy for business cycle correlation (Dbcc), we calculate average business cycle correlation for every country group. If in one country business cycle correlation is higher than the country group average the dummy is set equal to one. The dummy is zero if the degree of business cycle correlation is below average.

Second an alternative dummy (index) is constructed based on output gaps. For this purpose, output gaps for all countries in the sample including the country providing the anchor currency for exchange rate stabilization are computed. Then, the absolute value of the differences between the output gap (the deviation of the growth rate from the period average) of every single country in our sample and the reference country as listed in Table 1 is compiled and multiplied by $(-1){ }^{4}$ If the output gap of a country in our sample and the output gap of the respective reference country are identical the optimum value of the index for business cycle correlation is zero. The more the output gaps between anchor and periphery country diverge, the larger will be the negative value of the index for business cycle correlation.

[Insert Figure 2 here]

\footnotetext{
${ }^{4}$ index $_{i}=-\mid$ outputgap $_{i}-$ outputgap $_{j} \mid$ with $\mathrm{i}$ being the countries of our sample and $\mathrm{j}$ being the reference countries, Germany for the European countries, France for Germany, and the US for the rest of the world.
} 
Based on the theoretical literature we would expect a trade-off between exchange rate flexibility/volatility and price flexibility. Countries with a high degree of exchange rate stability have to exhibit a higher degree of wage and price flexibility to adjust to asymmetric shocks. Countries, which allow for more exchange rate flexibility could allow for more wage rigidity. This is shown in Figure 2, which compares producer price flexibility for the corner solutions in the choice of exchange rate regime in the new member states of the European Union. Whereas Poland and the Czech Republic have opted for a high degree of exchange rate flexibility, Estonia and Latvia have chosen tight exchange rate pegs. Figure 1 clearly reveals the relative high degree of producer price flexibility in the Baltic countries compared to Poland and the Czech Republic, particularly in recessions.

\subsection{Model Specification and Estimation Procedure}

We analyze the impact of exchange rate flexibility/volatility and price flexibility on growth contingent on business cycle correlation. Equation (1) is the benchmark equation as found in the empirical growth literature (see for instance Chang, Kaltani and Loayza 2009). The explanatory variables are the indicators of exchange rate volatility, price flexibility and control variables. In addition to country fixed effects, time fixed effects for the years 1994 to 2009 are included.

$$
w_{i t}=\gamma_{i}+\alpha \text { ERvol }_{i t}+\beta \text { Pflex }_{i t}+Z_{i t} \Gamma+u_{i t}
$$

Where $\mathrm{w}_{\mathrm{it}}$ are the yearly real growth rates from 1994 to 2009. ERvol stands for the three measures of exchange rate volatility as described above (standard deviations, mean of percent exchange rate changes against the anchor currency, z-score). Pflex is the proxy for price flexibility measured in the same way as exchange rate volatility in terms of standard deviations of the producer price index, means of monthly percent changes and a combination of both. The vector $Z_{\text {it }}$ represents the control variables.

We control for the short-term interest rates of the respective reference country as one of the most important determinant of global growth. Average inflation, proxied by the average of monthly year-over-year changes of the consumer price index controls for (negative) growth effects originating in macroeconomic instability (which is linked to exchange rate volatility). We control for the fact that more asymmetric countries face bigger constraints to achieve the same growth by 
using the index for the synchronization of output gaps (index). Furthermore, we control for a different impact of our explanatory variables in recession periods with the help of our recession dummy which is equal to one when the growth rate is negative.

There is a large number of other potential explanatory variables like investment, government spending, which could increase the fit of the model, but also generate endogeneity (for instance investment and growth) and multicollinetarity bias (for instance between government spending and inflation) (De Grauwe and Schnabl 2008). Therefore, we opt for a more parsimonious specification, restricted to the control variables mentioned above.

Our objective is twofold: to highlight the impact of exchange rate stability and price flexibility on growth and to disentangle the role played by countries with asymmetric business cycles (which we call asymmetric countries). Our prior is that the impact of exchange rate volatility and that of price flexibility, if any, should be restricted to asymmetric countries. In a second step, we introduce therefore the dummy for business cycle correlation, which is interacted with exchange rate volatility and price flexibility. The dummy is set equal to one for countries below the average regional business cycle correlation.

$$
w_{i t}=\gamma_{i}+\alpha_{1} E_{\text {Rvol }}+\alpha_{2} \text { ERvol }_{i t} * \operatorname{Dbcc}_{1}+\beta_{1} \text { Pflex }_{i t}+\beta_{2} \text { Pflex }_{i t} * \operatorname{Dbcc}_{1}+Z_{i t} \Gamma+u_{i t}
$$

In a third step, as a robustness check, we interact exchange rate volatility and price flexibility with the recession dummy to identify a possibly different impact in recessions.

$$
w_{i t}=\gamma_{i}+\alpha_{1} \text { ERvol }_{i t}+\alpha_{2} \text { ERvol }_{i t}^{*} \text { Drec }+\beta_{1} \text { Pflex }_{i t}+\beta_{2} \text { Pflex }_{i t} * \text { Drec }+Z_{i t} \Gamma+u_{i t}
$$

Fixed effect models are estimated to address the omitted variables bias and the heterogeneity of the sample, which includes countries at different stages of economic development. There is a core concern about endogeneity, as the incentive for depreciating exchange rates increases in recessions and/or when asymmetric shocks happen. Endogeneity is also likely to affect the price flexibility variable, as fast growing countries are more prone to be flexible, having more room for price adjustment. To address those sources of endogeneity, GMM analysis will be used (Arellano and Bond, 1991) in addition to fixed effects OLS regressions.

\subsection{Estimation Results}


The estimation results for the period from 1994 to 2009 provide evidence of a significant correlation between exchange rate volatility and growth as well as between price flexibility and growth. Higher exchange rate volatility has a strong negative impact on growth, while more price flexibility contributes to a higher growth performance. Those results are robust and hold whatever indicator for exchange rate volatility and price flexibility (standard deviation $\sigma$, average yearly change $\mu$, and z-score) is used. Their effect is economically important. According to column 2.1, a ten percent decrease in exchange rate volatility leads to a 0.87 increase in annual growth, while a ten percent increase in price flexibility allows a 0.12 increase in annual growth. Control variables coefficients are significant and have the expected signs. More average inflation deters growth, and lower interest rates in the reference country imply more opportunities for investment, which translates into higher growth. Growth rates are lower during periods of recession and when asymmetric shocks prevail. The results remain qualitatively the same whatever the econometric procedure (fixed effects or GMM) is.

\section{[Insert Table 2 here]}

The findings turn out to be driven by asymmetric countries. Table 3 displays the estimates of equation 2 for exchange rate volatility and price flexibility interacted with the asymmetric countries dummy. As reflected in columns 3.1 to 3.6, the interaction terms capture most of the impact of exchange rate volatility and price flexibility on growth. The non-interacted coefficients of exchange rate volatility and price flexibility are no more significant, while the interacted coefficients are significant, meaning that the effects of exchange volatility and price flexibility are restricted to asymmetric countries. Those findings support our view that exchange rate stability increases the growth performance and that countries with asymmetric business cycles have better to resort to internal adjustment to cope with recessions and/or asymmetric shocks. Internal adjustment tools like price and wage flexibility serve the objective of a dynamic longterm growth performance while at the same time correcting cyclical imbalances.

We run the same equation for the three indicators of exchange rate volatility (standard deviation $\sigma$, yearly change $\mu$, and z-score) and three indicators of price flexibility (standard deviation $\sigma$, yearly change $\mu$, and z-score). Except for the z-score indicators, our findings are robust and qualitatively the same.

[Insert Table 3 here] 
Table 4 reports the estimates of equation 3 for exchange rate volatility and price flexibility interacted with the recession dummy. This specification isolates the impact of exchange volatility and price flexibility on growth during the recessions. The table shows that countries tend to allow for more exchange rate flexibility during recessions, which translates into lower growth. The non-interacted exchange rate variable has no impact on growth. Price flexibility affects positively long-run growth as expected. However, this effect does not turn out to be more pronounced during recessions. In all cases, the non-interacted variable is significant at $1 \%$, while in three out of six cases the combined interacted and non-interacted variables are significant at $5 \%$. Overall those results suggest that like for asymmetric countries, countries experiencing crisis have better to adjust through internal prices rather than by resorting to exchange rates.

\section{[Insert Table 4 here]}

\section{Conclusion}

In the light of the most recent global wave of crisis the discussion about the role of the exchange rate for the adjustment of asymmetric shocks has been revived. In general, in the spirit of Mundell (1961) exchange rate devaluation in the face of crisis is widely regarded as an appropriate tool to return to sustainable growth. However, the Keynesian adjustment strategies neglect the possibly negative impact of expansionary macroeconomic policies on the marginal efficiency of investment as stressed by Schumpeter (1911) and Hayek (1931).

Based on the discussion of the seminal theoretical literature on exchange rate based shock adjustment we find that the benefits of depreciation in recessions depend on the time horizon. From a short-term perspective devaluations seem beneficial as they help to jumpstart investment and exports without dire austerity. From a more long-term perspective exchange rate stability during crisis is beneficial as the crisis countries are forced to adjust by wage cuts, price cuts and productivity increases. A higher (average) marginal efficiency of investment contributes to robust long-term growth.

Our empirical estimations provide evidence in favor of a positive impact of exchange rate stability and price flexibility on growth. This finding is robust concerning the choice of the exchange rate volatility measure and the price flexibility measure. This finding is driven (in the 
sense of Mundell 1961) by countries with asymmetric business cycles, which have - given exchange rate stability - to rely on productivity and wage adjustments to cope with shocks. The need for adjustment arises in specific in recession periods, whereas during booms exchange rate stability can be linked to rising wages and a loss of competitiveness.

The economic policy conclusion is that during crisis and in particular during the recovery after crisis interest rates should not be kept too low for too long to avoid competitive depreciations. Otherwise, the necessary adjustment process after the exuberance during the boom would be postponed and distorted economic structures would be conserved. This would paralyze the longterm growth performance of single countries, integrated regions and the whole world. For Europe we recommend continuing the monetary integration process, as - given our estimation results the euro seems beneficial from both a microeconomic and macroeconomic perspective. 


\section{References}

Aghion, Philippe et al. (2009): Exchange Rate Volatility and Productivity Growth: the Role of Financial Development. Journal of Monetary Economics 56, 494-513.

Arellano, Manuel / Bond, Stephen (1991): Some Tests of Specification for Panel Data: Monte Carlo Evidence and an Application to Employment Equations. Review of Economic Studies $58,2,277-297$.

Babetski, Jan / Boone, Laurence / Maurel, Mathilde (2004): Exchange Rate Regimes and Supply Shocks Asymmetry: the Case of the Accession Countries. Journal of Comparative Economics, $32,212-229$.

Bentivogli, Chiara / Pagano, Patrizio (1999): Regional Disparities and Labour Mobility: the Euro-11 versus the USA. LABOUR, CEIS, Fondazione Giacomo Brodolini and Blackwell Publishing Ltd 13, 3, 737-760.

Bernanke, Ben (2009): The Crisis and the Policy Response. At the Stamp Lecture, London School of Economics, 13.1. 2009.

Blanchard Olivier / Katz, Lawrence (1992): Regional Evolutions. Brookings Papers on Economic Activity 23, 1-76.

Calvo, Guillermo / Reinhart, Carmen (2002): Fear Of Floating. The Quarterly Journal of Economics 117, 2, 379-408.

Cerra, Valerie / Panizza, Ugo / Saxena, Sweta (2009): International Evidence on Recovery from Recessions. IMF Working Paper 09/183.

Cerra, Valerie / Saxena, Sweta (2008): Growth Dynamics: The Myth of Economic Recovery. American Economic Review 98, 1, 439-57.

Chang, Roberto / Kaltani, Linda / Loayza, Norman (2009), Openness Can be Good for Growth: The Role of Policy Complementarities. Original Research Article Journal of Development Economics 90, 1, 33-49.

Corricelli, Fabrizio / Mathilde Maurel (2010): Growth and Crisis in Transition: A Comparative Perspective. Review of International Economics, forthcoming.

Decressin, Jorg/ Fatas, Antonio (1995): Regional Labor Market Dynamics in Europe. European Economic Review 39, 9, 1627-1655.

De Grauwe, Paul / Schnabl, Gunther (2008): Exchange Rate Stability, Inflation and Growth in (South) Eastern and Central Europe. Review of Development Economics 12, 3, 530-549.

Duchêne, Gérard / Maurel, Mathilde/ Najman, Boris (2004): Elargissement de l'UE: Présentation Générale, Economie et Prévision 163.

Eichengreen, Barry (2002): Financial Crises and What to Do About Them, Oxford.

Eichengreen, Barry / Hausmann, Ricardo (1999): Exchange Rates and Financial Fragility. In: New Challenges for Monetary Policy, Kansas City: Federal Reserve Bank 
of Kansas City, 329-368.

Fidrmuc, Jan (2004): Migration and Regional Adjustment to Asymmetric Shocks in Transition Economies. Journal of Comparative Economics 32, 2, 230-247.

Fidrmuc, Jan / Maurel, Mathilde (2004): Optimum Choice of the exchange-rate regime for the accession candidate countries. Journal of Comparative Economics 32, 2, 197-201.

Fischer, Stanley (2001): Distinguished Lecture on Economics in Government-Exchange Rate Regimes: Is the BipolarView Correct? Journal of Economic Perspectives 15, 2, 3-24.

Flood, Robert / Garber, Peter (1984): Collapsing Exchange-Rate Regimes: Some Linear Examples. Journal of International Economics 17, 1-2, 1-13.

Greenspan, Alan (2007): The Age of Turbulence, New York.

Hawtrey, Ralph (1919): The Gold Standard, Economic Journal 3, 428-442.

Hayek, Friedrich von (1929): Geldtheorie und Konjunkturtheorie, Salzburg.

Hayek, Friedrich von (1931): Prices and Production, London.

Hayek, Friedrich von (1937): Monetary Nationalism and International Stability, London.

Hoffmann, Andreas / Schnabl, Gunther (2009): A Vicious Cycle of Financial Market Exuberance, Panics and Asymmetric Policy Response - An Overinvestment View. CESifo Working Paper 1288.

Keynes, John Maynard (1936): The General Theory of Employment, Interest, and Money, London.

McKinnon, Ronald / Schnabl, Gunther (2004a): The Return to Soft Dollar Pegging in East Asia? Mitigating Conflicted Virtue. International Finance 7, 2, 169-201.

McKinnon, Ronald / Schnabl, Gunther (2004b): The East Asian Dollar Standard, Fear of Floating, and Original Sin. Review of Development Economics 8, 3, 331-360.

Mundell, Robert (1961): A Theory of Optimum Currency Areas, American Economic Review 51, 4, 657-665.

Parente, Stephen / Prescott, Edward (2005): A Unified Theory of the Evolution of International Income Levels. In Aghion, Philippe / Durlauf, Steven (eds.): Handbook of Economic Growth 1, 1371-1416.

Purfield, Catriona / Rosenberg, Christoph (2010): Adjustment under a Currency Peg: Estonia, Latvia and Lithuania during the Global Financial Crisis 2008-09. IMF Working Paper 10/213.

Rose, Andrew (2004): A Meta-Analysis of the Effect of Common Currencies on International Trade. NBER Working Paper 10373. 
Schnabl, Gunther (2009): Exchange Rate Volatility and Growth in Emerging Europe and East Asia. Open Economies Review 20, 565-587.

Schnabl, Gunther / Hoffmann, Andreas (2008): Monetary Policy, Vagabonding Liquidity and Bursting Bubbles in New and Emerging Markets - An Overinvestment View. The World Economy 31, 9, 1226-1252.

Schnabl, Gunther / Zemanek, Holger (2010): Germany, Greece, France and Beyond - InterTemporal Savings, Current Account Imbalances and Asymmetric Shocks in a Heterogeneous Monetary Union. Mimeo.

Sinn, Hans-Werner (2010): The Financial Crisis: the Way Forward. CESifo Forum 11, 3, 12-19.

Schumpeter, Josef (1911): Theorie der Wirtschaftlichen Entwicklung, Berlin. 
Figure 1: Growth Rates and Business Cycle Synchronization

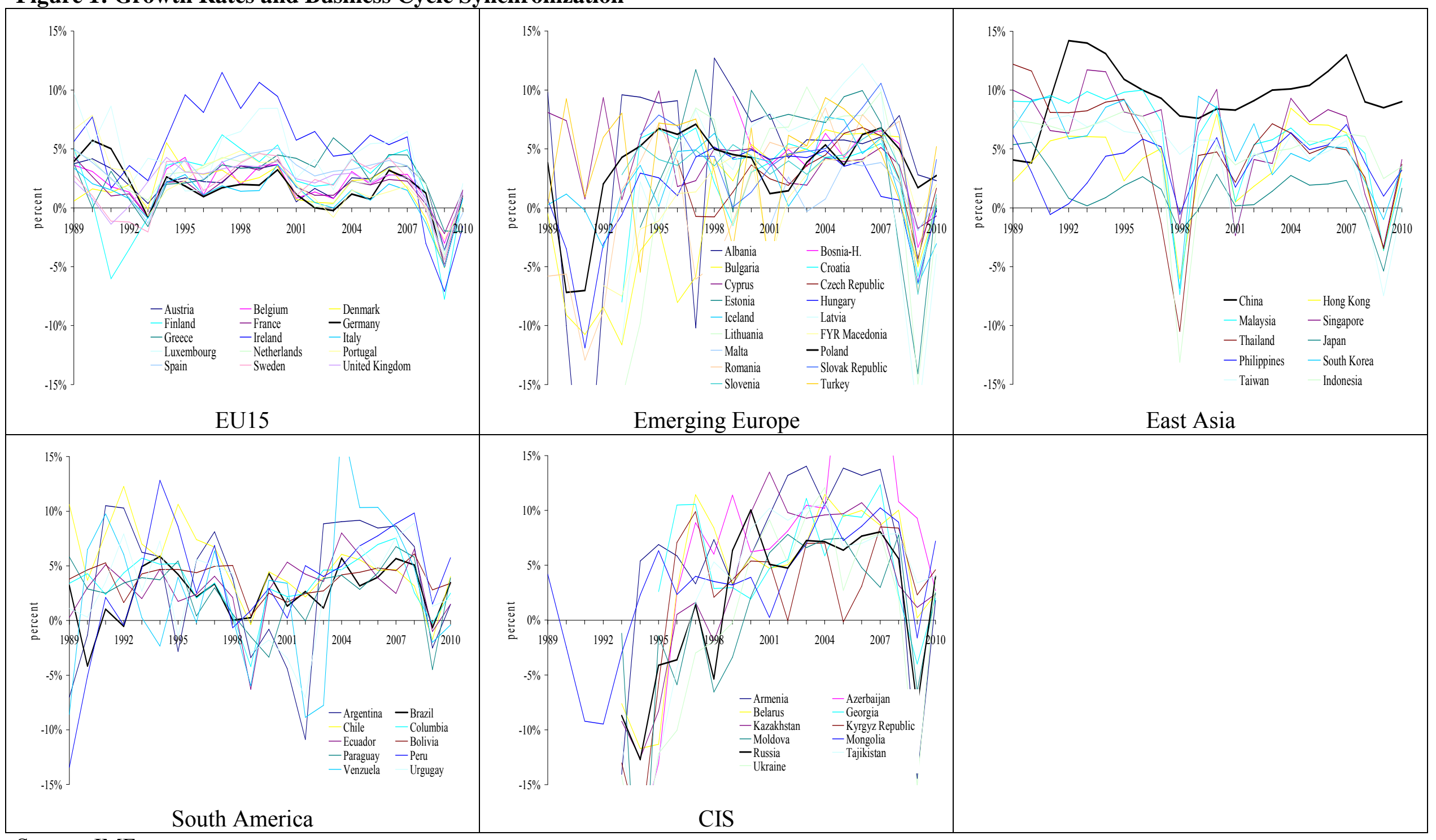

Source: IMF. 
Table 1: Sample by Country Groups, Exchange Rate Anchor and Reference Country for Business Cycle Correlation

\begin{tabular}{lll}
\hline Country Group & $\begin{array}{l}\text { Anchor } \\
\text { Reference Country }\end{array}$ & Countries \\
\hline EU15 & $\begin{array}{l}\text { Euro/DM } \\
\text { Germany }\end{array}$ & $\begin{array}{l}\text { Austria, Belgium, Denmark, Finland, France, } \\
\text { Germany*, Greece, Ireland, Italy, Luxemburg, } \\
\text { Netherlands, Portugal, Spain, Sweden, UK }\end{array}$ \\
\hline Emerging Europe & $\begin{array}{l}\text { Euro/DM } \\
\text { Germany }\end{array}$ & $\begin{array}{l}\text { Bulgaria, Czech Republic, Estonia, Hungary, } \\
\text { Latvia, Lithuania, Poland, Romania, Slovak Rep., } \\
\text { Slovenia, Albania, Bosnia-Herzegovina, Croatia, } \\
\text { Macedonia, Serbia, Turkey }\end{array}$ \\
& Dollar & $\begin{array}{l}\text { China, Hong Kong, Indonesia, Japan, Malaysia, } \\
\text { Ehilippines, Singapore, South Korea, Taiwan, } \\
\text { Thailand }\end{array}$ \\
\hline South America & Dollar & Argentina, Bolivia, Brazil, Chile, Columbia, \\
& US & Ecuador, Paraguay, Peru, Uruguay, Venezuela \\
\hline CIS & Dollar & Armenia, Azerbaijan, Belarus, Georgia, \\
& KS & Kazakhstan, Kyrgyz Republic, Moldova, Russia, \\
& Ukraine
\end{tabular}

* For Germany, France as the second largest country of the European Union is used as a reference country. 
Figure 2: Producer Price Flexibility in Central and Eastern Europe

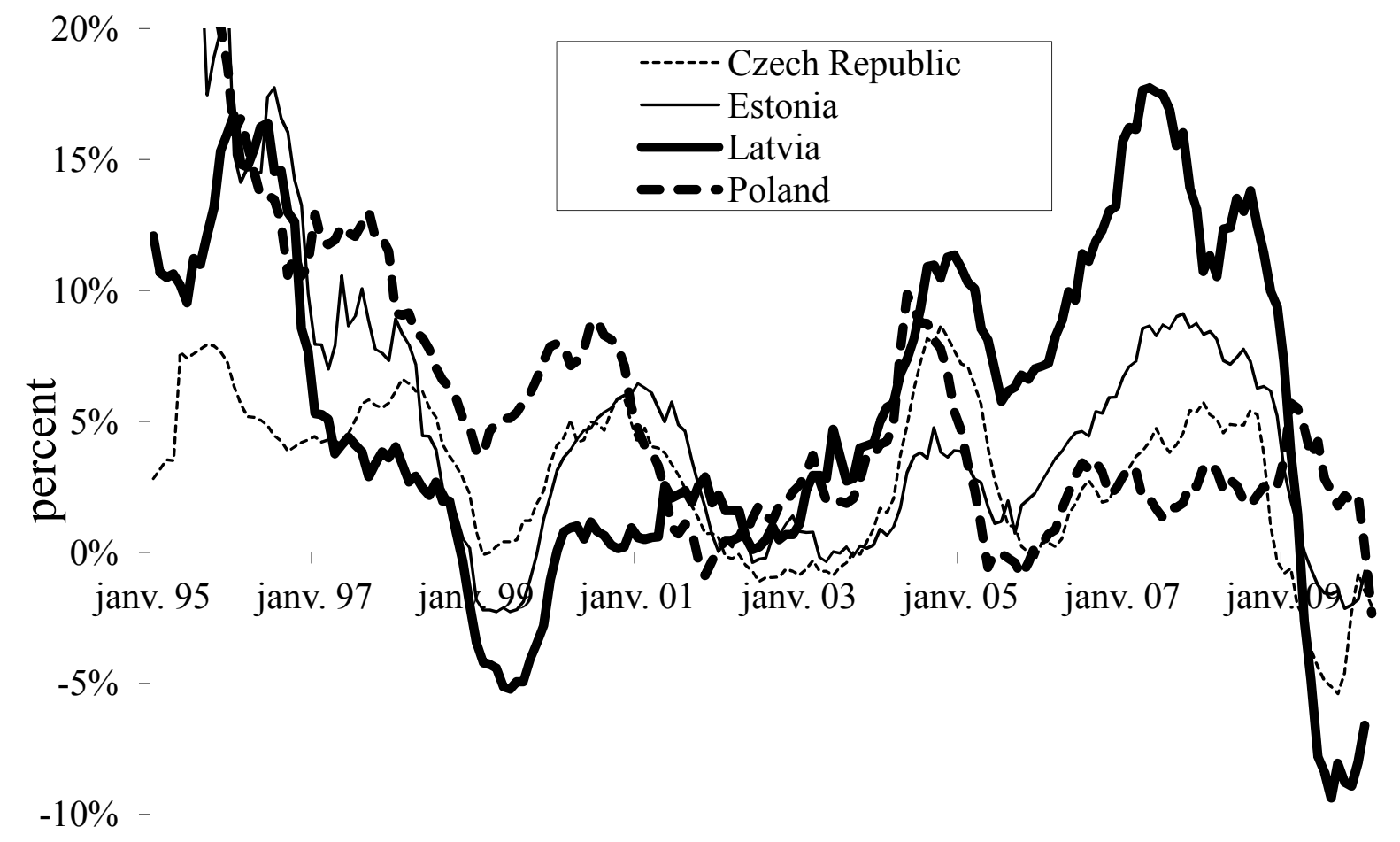

Source: IMF 
Table 2: Estimation Results of Equation (1), 1994-2009

$\begin{array}{llllll}\text { OLS } & \text { GMM } & \text { OLS } & \text { GMM } & \text { OLS } & \text { GMM } \\ 2.1 & 2.2 & 2.3 & 2.4 & 2.5 & 2.6\end{array}$

\section{Exchange rate volatility}

$\begin{array}{lll}\text { Standard deviation } \sigma & -0.087 * * * & -0.102 * * * \\ & (0.023) & (0.017)\end{array}$

Yearly Change $\mu$

$\begin{array}{ll}-0.112 * * * & -0.080 * * * \\ (0.042) & (0.031)\end{array}$

Z-score

$\begin{array}{ll}-0.075 * * * & -0.078 * * * \\ (0.021) & (0.013)\end{array}$

Price flexibility

$\begin{array}{lll}\text { Standard deviation } \sigma & \begin{array}{ll}0.012 * * * & 0.014 * * * \\ (0.002) & (0.001)\end{array}\end{array}$

Yearly Change $\mu$

Z-score

$\begin{array}{ll}0.006 * * * & 0.009 * * * \\ (0.001) & (0.000)\end{array}$

\begin{tabular}{|c|c|c|c|c|c|c|}
\hline & \multirow{2}{*}{$(0.000)$} & \multirow{2}{*}{$\begin{array}{l}(0.000) \\
0.126^{* * *} \\
(0.013)\end{array}$} \\
\hline Lagged growth & & $\begin{array}{l}0.150 * * * \\
(0.014)\end{array}$ & & $\begin{array}{l}0.151 * * * \\
(0.012)\end{array}$ & & \\
\hline \multicolumn{7}{|l|}{ Control variables } \\
\hline Average inflation & $\begin{array}{l}-0.005 * * * \\
(0.000)\end{array}$ & $\begin{array}{l}-0.003 * * * \\
(0.000)\end{array}$ & $\begin{array}{l}-0.006 * * * \\
(0.000)\end{array}$ & $\begin{array}{l}-0.006 * * * \\
(0.000)\end{array}$ & $\begin{array}{l}-0.005 * * * \\
(0.000)\end{array}$ & $\begin{array}{l}-0.006 * * * \\
(0.000)\end{array}$ \\
\hline Interest rate of reference country & $\begin{array}{l}-0.121 * * * \\
(0.011)\end{array}$ & $\begin{array}{l}-0.119 * * * \\
(0.005)\end{array}$ & $\begin{array}{l}-0.117 * * * \\
(0.011)\end{array}$ & $\begin{array}{l}-0.114 * * * \\
(0.004)\end{array}$ & $\begin{array}{l}-0.120 * * * \\
(0.011)\end{array}$ & $\begin{array}{l}-0.129 * * * \\
(0.006)\end{array}$ \\
\hline Index & $\begin{array}{l}0.476 * * * \\
(0.047)\end{array}$ & $\begin{array}{l}0.608 * * * \\
(0.032)\end{array}$ & $\begin{array}{l}0.487 * * * \\
(0.047)\end{array}$ & $\begin{array}{l}0.536 * * * \\
(0.024)\end{array}$ & $\begin{array}{l}0.475 * * * \\
(0.047)\end{array}$ & $\begin{array}{l}0.573 * * * \\
(0.034)\end{array}$ \\
\hline Recession dummy & $\begin{array}{l}-0.051 * * * \\
(0.002)\end{array}$ & $\begin{array}{l}-0.048 * * * \\
(0.002)\end{array}$ & $\begin{array}{l}-0.051 * * * \\
(0.002)\end{array}$ & $\begin{array}{l}-0.051 * * * \\
(0.001)\end{array}$ & $\begin{array}{l}-0.051 * * * \\
(0.002)\end{array}$ & $\begin{array}{l}-0.045 * * * \\
(0.002)\end{array}$ \\
\hline Fixed effects & Yes & & Yes & & Yes & \\
\hline Number of obs. & 765 & 723 & 765 & 723 & 765 & 723 \\
\hline R2 within & 0.6712 & & 0.6730 & & 0.6735 & \\
\hline $\mathrm{R} 2$ overall & 0.5372 & & 0.5389 & & 0.5419 & \\
\hline Wald & & 9975 & & 26316 & & 43843 \\
\hline
\end{tabular}

Data source: IMF, national central banks. *Significant at 10\%; **Significant at 5\%; ***Significant at $1 \%$. 
Table 3: Estimation Results of Equation (2), 1994-2009

$\begin{array}{llllll}\text { OLS } & \text { GMM } & \text { OLS } & \text { GMM } & \text { OLS } & \text { GMM } \\ 3.1 & 3.2 & 3.3 & 3.4 & 3.5 & 3.6\end{array}$

\section{Exchange rate volatility}

$$
\text { Standard deviation } \sigma
$$

Standard deviation $\sigma$ times dummy

$=1$ for asymmetric countries

Yearly Change $\mu$

Yearly Change $\mu$ times dummy $=1$ for asymmetric countries

Z-score

Z-score times dummy $=1$ for asymmetric countries

\section{Price flexibility}

Standard deviation $\sigma$

Standard deviation $\sigma$ times dummy

$=1$ for asymmetric countries

Yearly Change $\mu$

Yearly Change $\mu$ times dummy $=1$ for asymmetric countries z-score

$\mathrm{Z}$-score times dummy $=1$ for asymmetric countries

Lagged growth

\section{Control variables}

Average inflation

Interest rate of reference country

Index

Recession dummy

Fixed effects

Number of obs.

R2 within

R2 overall

Wald

Data sou

$\begin{array}{ll}0.00 & 0.044 \\ (0.028) & (0.028) \\ -0.20 * * * & - \\ (0.039) & 0.183 * * * \\ & (0.029)\end{array}$

$\begin{array}{ll}-0.027 & -0.038 * \\ (0.048) & (0.022) \\ - & - \\ 0.290 * * * & 0.337 * * * \\ (0.088) & (0.053)\end{array}$

$-0.045^{*} \quad-$

(0.026) $\quad 0.061 * * *$

(0.020)

$-0.072 * \quad-$

(0.04) $\quad 0.046 * * *$

(0.018)
$-0.026 \quad-0.05$
$(0.028) \quad(0.007)$
$0.038 \quad 0.018 * *$
$(0.038)$
(0.008)

$\begin{array}{ll}-0.014 & -0.003 \\ (0.009) & (0.002) \\ 0.020 * * & 0.008 * * * \\ (0.009) & (0.002)\end{array}$

$0.155^{* * *}$

$-0.006 \quad 0.003 * * *$

$(0.009) \quad(0.001)$

$0.011 \quad 0.000$

$(0.009) \quad(0.001)$

(0.014)

$0.127 * * *$

$0.130 * * *$

(0.016)

$\begin{array}{llllll}- & - & - & - & - & - \\ 0.004 * * * & 0.003 * * * & 0.004 * * * & 0.002 * * * & 0.005 * * * & 0.002 * * * \\ (0.000) & (0.001) & (0.001) & (0.000) & (0.000) & (0.000) \\ - & - & - & - & - & - \\ 0.125 * * * & 0.122 * * * & 0.125 * * * & 0.125 * * * & 0.122 * * * & 0.121 * * * \\ (0.011) & (0.006) & 0.011) & (0.007) & (0.011) & (0.006) \\ 0.416^{* * *} & 0.480 * * * & 0.459 * * * & 0.479 * * * & 0.452 * * * & 0.514 * * * \\ (0.052) & (0.039) & (0.050) & (0.054) & (0.054) & (0.046) \\ - & - & - & - & - & -0051 * * * \\ 0.049 * * * & 0.047 * * * & 0.050^{* * *} & 0.051 * * * & 0.050 * * * & (0.002) \\ (0.002) & (0.002) & (0.002) & (0.002) & (0.002) & \\ \text { Yes } & & \text { Yes } & & \text { Yes } & \\ 765 & 723 & 765 & 723 & 765 & 723 \\ 0.6830 & & 0.679 & & 0.6753 & \\ 0.5527 & & 0.543 & & 0.5428 & \\ & 42018 & & 26316 & & 6898\end{array}$




\begin{tabular}{llllll} 
OLS & GMM & OLS & GMM & OLS & GMM \\
4.1 & 4.2 & 4.3 & 4.4 & 4.5 & 4.6 \\
\hline
\end{tabular}

\begin{tabular}{|c|c|c|c|c|c|c|}
\hline \multicolumn{7}{|l|}{ Exchange rate volatility } \\
\hline Standard deviation $\sigma$ & $\begin{array}{l}0.044 \\
(0.069)\end{array}$ & $\begin{array}{l}0.041 \\
(0.062)\end{array}$ & & & & \\
\hline $\begin{array}{r}\text { Standard deviation } \sigma \text { times dummy } \\
=1 \text { for recession }\end{array}$ & $\begin{array}{l}-0.117^{*} \\
(0.072)\end{array}$ & $\begin{array}{l}-0.134 * * \\
(0.076)\end{array}$ & & & & \\
\hline Yearly Change $\mu$ & & & $\begin{array}{l}0.003 \\
(0.064)\end{array}$ & $\begin{array}{l}-0.106 \\
(0.073)\end{array}$ & & \\
\hline $\begin{array}{r}\text { Yearly Change } \mu \text { times dummy }=1 \\
\text { for recession }\end{array}$ & & & $\begin{array}{l}-0.173 * * \\
(0.082)\end{array}$ & $\begin{array}{l}-0.024 \\
(0.087)\end{array}$ & & \\
\hline z-score & & & & & $\begin{array}{l}0.005 \\
(0.053)\end{array}$ & $\begin{array}{l}-0.015 \\
(0.067)\end{array}$ \\
\hline $\begin{array}{r}\text { z-score times dummy }=1 \text { for } \\
\text { recession }\end{array}$ & & & & & $\begin{array}{l}-0.074 \\
(0.057)\end{array}$ & $\begin{array}{l}-0.039 \\
(0.070)\end{array}$ \\
\hline \multicolumn{7}{|l|}{ Price flexibility } \\
\hline Standard deviation $\sigma$ & $\begin{array}{l}0.014 * * * \\
(0.003)\end{array}$ & $\begin{array}{l}0.014 * * * \\
(0.004)\end{array}$ & & & & \\
\hline $\begin{array}{r}\text { Standard deviation } \sigma \text { times dummy } \\
=1 \text { for recession }\end{array}$ & $\begin{array}{l}-0.010^{* *} \\
(0.005)\end{array}$ & $\begin{array}{l}-0.004 \\
(0.004)\end{array}$ & & & & \\
\hline Yearly Change $\mu$ & & & $\begin{array}{l}0.006^{* * *} \\
(0.001)\end{array}$ & $\begin{array}{l}0.011 * * * \\
(0.001)\end{array}$ & & \\
\hline $\begin{array}{r}\text { Yearly Change } \mu \text { times dummy }=1 \\
\text { for recession }\end{array}$ & & & $\begin{array}{l}-0.002 \\
(0.002)\end{array}$ & $\begin{array}{l}0.004 * * * \\
(0.001)\end{array}$ & & \\
\hline z-score & & & & & $\begin{array}{l}0.005^{* * *} \\
(0.001)\end{array}$ & $\begin{array}{l}0.010 * * * \\
(0.000)\end{array}$ \\
\hline$z$-score times dummy $=1$ for & & & & & -0.003 & - \\
\hline recession & & & & & $(0.002)$ & $\begin{array}{l}0.005^{* * *} \\
(0.000)\end{array}$ \\
\hline Lagged growth & & $\begin{array}{l}0.148 * * * \\
(0.012)\end{array}$ & & $\begin{array}{l}0.121 * * * \\
(0.011)\end{array}$ & & $\begin{array}{l}0.136^{* * *} \\
(0.008)\end{array}$ \\
\hline \multicolumn{7}{|l|}{ Control variables } \\
\hline \multirow[t]{2}{*}{ Average inflation } & - & - & - & - & - & - \\
\hline & $\begin{array}{l}0.005^{* * *} \\
(0.000)\end{array}$ & $\begin{array}{l}0.003 * * * \\
(0.000)\end{array}$ & $\begin{array}{l}0.006^{* * *} \\
(0.001)\end{array}$ & $\begin{array}{l}0.007 * * * \\
(0.000)\end{array}$ & $\begin{array}{l}0.006^{* * *} \\
(0.000)\end{array}$ & $\begin{array}{l}0.007 * * * \\
(0.000)\end{array}$ \\
\hline \multirow[t]{2}{*}{ Interest rate of reference country } & - & - & - & - & - & \\
\hline & $\begin{array}{l}0.123 * * * \\
(0.011)\end{array}$ & $\begin{array}{l}0.119 * * * \\
(0.006)\end{array}$ & $\begin{array}{l}0.121 * * * \\
(0.011)\end{array}$ & $\begin{array}{l}0.123 * * * \\
(0.005)\end{array}$ & $\begin{array}{l}0.122 * * * \\
(0.011)\end{array}$ & $\begin{array}{l}0.124 * * * \\
(0.004)\end{array}$ \\
\hline Index & $\begin{array}{l}0.478 * * * \\
(0.047)\end{array}$ & $\begin{array}{l}0.567 * * * \\
(0.035)\end{array}$ & $\begin{array}{l}0.479 * * * \\
(0.046)\end{array}$ & $\begin{array}{l}0.598 * * * \\
(0.026)\end{array}$ & $\begin{array}{l}0.476 * * * \\
(0.047)\end{array}$ & $\begin{array}{l}0.538^{* * *} \\
(0.019)\end{array}$ \\
\hline \multirow[t]{2}{*}{ Recession dummy } & - & - & - & - & - & - \\
\hline & $\begin{array}{l}0.048 * * * \\
(0.002)\end{array}$ & $\begin{array}{l}0.045^{* * *} \\
(0.002)\end{array}$ & $\begin{array}{l}0.049 * * * \\
(0.002)\end{array}$ & $\begin{array}{l}0.046^{* * *} \\
(0.002)\end{array}$ & $\begin{array}{l}0.049 * * * \\
(0.002)\end{array}$ & $\begin{array}{l}0.046^{* * *} \\
(0.001)\end{array}$ \\
\hline Fixed effects & Yes & & Yes & & Yes & \\
\hline Number of obs. & 765 & 723 & 765 & 723 & 765 & 723 \\
\hline R2 within & 0.6755 & & 0.6774 & & 0.6763 & \\
\hline $\mathrm{R} 2$ overall & 0.5412 & & 0.5447 & & 0.5435 & \\
\hline Wald & & 4487 & & 19963 & & 20436 \\
\hline
\end{tabular}

Data source: IMF, Central Banks. *Significant at $10 \%$; **Significant at $5 \%$; ***Significant at $1 \%$. 